MATEC Web of Conferences 22,05002 (2015)

DOI: $10.1051 /$ matecconf/ 20152205002

(C) Owned by the authors, published by EDP Sciences, 2015

\title{
Effects of Different Solvents on the Planar Hetero-junction Perovskite Solar Cells
}

\author{
Shunquan Lin*, Wei Li, Haocheng Sun, Wei Xu, Wenping Guo, Min Xia \& Kecheng Yang \\ School of Optical and Electronic Information, Huazhong University of Science and Technology, Wuhan, Hubei, \\ China
}

\begin{abstract}
The perovskite $\left(\mathrm{CH}_{3} \mathrm{NH}_{3} \mathrm{PbI}_{3}\right)$ films on the planar hetero-junction perovskite solar cells (PHJ-PSCs) are fabricated by "two-steps" process with the wet spin-coating method. The precursor (PbI2) solutions are compounded with 4 types of solvents: N-Methyl Pyrrolidone (NMP), $\gamma$-butyrolactone (GBL), Dimethyl Sulfoxide (DMSO) and N, N-dimethylformamide (DMF). All the solutions have the same concentration. The influences of different precursor solvents to the micro-structures of $\mathrm{CH}_{3} \mathrm{NH}_{3} \mathrm{PbI}_{3}$ films and device performance are studied. Atomic force microscopy (AFM) and scanning electron microscope (SEM) are used to characterize the $\mathrm{CH}_{3} \mathrm{NH}_{3} \mathrm{PbI}_{3}$ films. The results indicate that the $\mathrm{CH}_{3} \mathrm{NH}_{3} \mathrm{PbI}_{3}$ film using DMF solvent possesses more rough morphology and thickest thickness. The monolithic PHJ-PSCs devices based on DMF solvent are tested under a standard one sun of simulated solar irradiation (AM1.5). The results show that the open-circuit voltage (Voc) reaches $872 \mathrm{mV}$, the short-circuit current (Jsc) reaches $9.35 \mathrm{~mA} / \mathrm{cm} 2$, the filling factor(FF) is 0.62 and the photocurrent conversion efficiency (PCE) is $5.05 \%$. DMF is the best one among these 4 types of solvents for PHJ-PSCs.
\end{abstract}

Keywords: perovskite solar cells; CH3NH3PbI3 films; DMF solvent; wet spin-coating method

\section{INTRODUCTION}

Organic photovoltaics $(\mathrm{OPV})^{[1-3]}$, dye sensitized solar cells (DSSCs) ${ }^{[4,5]}$ and organic/inorganic hybrid perovskite solar cells $(\mathrm{PSCs})^{[6,7]}$ have been intensively investigated as competitive ones to inorganic silicon solar cells due to their potential for cost-efficient, light-weight, and flexible device fabrication ${ }^{[8-10]}$. Among them, hybrid solar cells employing organic/inorganic perovskite materials (for example, $\mathrm{CH}_{3} \mathrm{NH}_{3} \mathrm{PbI}_{(3-\mathrm{x})} \mathrm{Cl}_{\mathrm{x}}$ and $\mathrm{CH}_{3} \mathrm{NH}_{3} \mathrm{PbI}_{3}$ ) with direct band-gaps, high absorption coefficients, long diffusion lengths, and excellent charge transport properties as light-harvesters and carrier conductors have been recently recognized as one of the new generation of promising photovoltaics which are capable of resolving the aforementioned challenges ${ }^{[11]}$.

Recently, more and more high-performance monolithic PSCs devices with high photo-current conversion efficiency (PCE) near $19.3 \%$ are reported ${ }^{[6,12,13]}$, which were realized by depositing perovskite materials $\left(\mathrm{CH}_{3} \mathrm{NH}_{3} \mathrm{PbI}_{3}\right.$ onto a mesostructured $\mathrm{TiO}_{2}$ scaffold acting as the electron transport layer ${ }^{[14-16]}$. With the long operating life and long diffusion lengths, the perovskite materials can be also applied on the planar hetero-junction(PHJ) structure PSC ${ }^{[17,18]}$, in which we can directly spin the perovskite materials on the conductive glass. The PCE reaches $15.4 \%$ reported by Mingzhen Liu ${ }^{[19]}$, and it is closed to the PCE reported with mesostructured.

To obtain a high-quality $\mathrm{TiO}_{2}$ mesostructure, the monolithic PSCs need thermal annealing process at a *Corresponding author: linsq0402@163.com relatively high temperature about $450^{\circ} \mathrm{C}$, and this process limits its widely application ${ }^{[6,14]}$. While the same process for PHJ-PSCs device applies much lower temperature as $140^{\circ} \mathrm{C}$, it can make the fabrication process simple and costless. These advantages are significant factors in developing high-efficiency, low-cost and flexible PSCs.

\section{METHOD}

In this paper, the crystalized perovskite is formed by using spin-coating and thermal annealing methods. $\mathrm{CH}_{3} \mathrm{NH}_{3} \mathrm{PbI}_{3}$ is taken as peroviskite material for its shorter thermal annealing time than $\mathrm{CH}_{3} \mathrm{NH}_{3} \mathrm{PbI}_{(3-\mathrm{x})} \mathrm{Cl}_{\mathrm{x}}$ In addition, the extinction coefficient of $\mathrm{CH}_{3} \mathrm{NH}_{3} \mathrm{PbI}_{3}$ is $1.5 \times 10^{-4} / \mathrm{cm}$ at $550 \mathrm{~nm}$, and the absorption range is $800 \mathrm{~nm}$ in the solar spectrum. This characteristic of absorption is more popular than most light-absorbing materials $^{[12,}$ 20].

$\mathrm{CH}_{3} \mathrm{NH}_{3} \mathrm{PbI}_{3}$ perovskite can be formed through one-or-two-step coating method. $\mathrm{CH}_{3} \mathrm{NH}_{3} \mathrm{I}, \mathrm{HI}$, and $\mathrm{PbI}_{2}$ are required to form $\mathrm{CH}_{3} \mathrm{NH}_{3} \mathrm{PbI}_{3}$. For one-step coating, $\mathrm{CH}_{3} \mathrm{NH}_{3} \mathrm{I}$ is first synthesized by reacting equimolar $\mathrm{CH}_{3} \mathrm{NH}_{2}$ and $\mathrm{HI}$ in the appropriate solvent The synthesized $\mathrm{CH}_{3} \mathrm{NH}_{3} \mathrm{I}$ is mixed with $\mathrm{PbI}_{2}$ at a $1: 1$ molar ratio in GBL at $60^{\circ} \mathrm{C}$ and is then used as a coating solution. The as-deposited perovskite on a metal oxide or the PEDOT:PSS surface must be heated to a temperature which is approximately $100^{\circ} \mathrm{C}$ to form the crystalline phase. $\mathrm{CH}_{3} \mathrm{NH}_{3} \mathrm{PbI}_{3}$ can be also formed through a two-step coating process where 
layered $\mathrm{PbI}_{2}$ forms first on a metal oxide or the PEDOT:PSS surface, and then the $\mathrm{PbI}_{2}$ film is immersed in a solution containing $\mathrm{CH}_{3} \mathrm{NH}_{3} \mathrm{I}$. One-or-two-step coating methods can be applied to fill the pores and produce a capping layer; however, the one-step coating method may lead to voids because a highly viscous coating solution is expected due to the high ionic strength both in $\mathrm{CH}_{3} \mathrm{NH}_{3} \mathrm{I}$ and $\mathrm{PbI}_{2}$. Therefore, the two-step coating method is preferred over the concrete perovskite ${ }^{[21]}$. So, in this paper, we used two-step method.

As we all know, the quality of $\mathrm{CH}_{3} \mathrm{NH}_{3} \mathrm{PbI}_{3}$ perovskite film has important influence on the efficiency of PHJ-PSCs. In one-step method, $\gamma$-butyrolactone (GBL), N, N-dimethyl formamide (DMF), dimethyl sulfoxide(DMSO) and N-methyl pyrrolidone (NMP) are the common solvents, and the GBL is prior ${ }^{[22]}$. But in two-step method, the solubility of precursor $\mathrm{PbI}_{2}$ in the GBL is more sensitive to temperature; it will occur to have precipitation at the room temperature. Thus, the GBL is not an optimal choice in two-step method. This paper discusses the optimal solvent using two-steps method among NMP, DMF, GBL and DMSO.

Basic structure of monolithic solar cell device is shown in figure 1 . The device is fabricated in a standard arrangement by sandwiching a PHJ of $\mathrm{CH}_{3} \mathrm{NH}_{3} \mathrm{PbI}_{3} / \mathrm{C} 60$ structure between the precleaned and prepatterned transparent glass/ITO/PEDOT:PSS as the positive electrode and the thin PCBM film as an EBL or HBL. The device is completed by the thermal

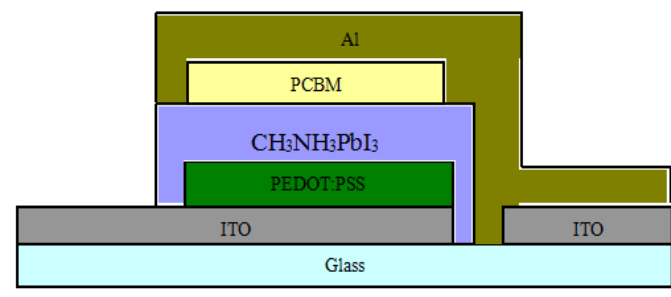

Figure 1. Structure of monolithic PHJ-PSCs

evaporation of $\mathrm{Al}$ as the negative electrode.

In order to study the effects of morphology of $\mathrm{CH}_{3} \mathrm{NH}_{3} \mathrm{PbI}_{3}$ perovskite film with different solvents through two-step method, we respectively use GBL, NMP, DMF, and DMSO as solvents of $\mathrm{PbI}_{2}$ to prepare spin-on liquid in the same concentration $500 \mathrm{mg} / \mathrm{ml}$ based on the speed of 3000rpm, and the thermal annealing is $100^{\circ} \mathrm{C}$ for $30 \mathrm{~min}$. Then the film with $\mathrm{PbI}_{2}$ soaks in the solution of $20 \mathrm{mg} / \mathrm{ml} \mathrm{CH}_{3} \mathrm{NH}_{3} \mathrm{I}$. In the end, the crystallization of $\mathrm{CH}_{3} \mathrm{NH}_{3} \mathrm{PbI}_{3}$ is generated after the thermal annealing.

\section{RESULTS AND DISCUSSION}

To analyze the qualities of $\mathrm{CH}_{3} \mathrm{NH}_{3} \mathrm{PbI}_{3}$ film., we use the atomic force microscope (AFM) to observe the surface morphology of $\mathrm{CH}_{3} \mathrm{NH}_{3} \mathrm{PbI}_{3}$ film, the scanning electron microscope (SEM) to observe thickness of $\mathrm{CH}_{3} \mathrm{NH}_{3} \mathrm{PbI}_{3}$ perovskite film, the X-ray diffractometer (XRD) to determine the major-constituent of $\mathrm{CH}_{3} \mathrm{NH}_{3} \mathrm{PbI}_{3}$ perovskite film, and the sun simulator to test the photo-voltaic performance of monolithic PHJ-PSCs device based on a standard one sun of simulated solar irradiation (AM1.5).

\subsection{Influence of the morphology controller on CH3NH3PbI3 perovskite film formation}

As shown in figure 2, the morphology of $\mathrm{CH}_{3} \mathrm{NH}_{3} \mathrm{PbI}_{3}$ film occurs to be an independent island structure of crystal nucleus with AFM by two-step method. When using NMP as solvent, the surface roughness of root mean square (RMS) value is $4.667 \mathrm{~nm}$ (figure 2a), which indicates the surface roughness of film. By contrast, the GBL is $11.962 \mathrm{~nm}$ (figure $2 \mathrm{~b}$ ), the DMSO is $21.316 \mathrm{~nm}$ (figure 2c), and the DMF is $24.549 \mathrm{~nm}$ (figure 2d). Combined with 3D morphology diagram in figure 2 , the crystal nucleus of $\mathrm{CH}_{3} \mathrm{NH}_{3} \mathrm{PbI}_{3}$ film is the largest, as the RMS is the maximum when using DMF as the solvent.

$\mathrm{PbI}_{2}$ solution affects the crystallization conditions of $\mathrm{CH}_{3} \mathrm{NH}_{3} \mathrm{PbI}_{3}$ with different solvent. The saturated vapor pressures of NMP, GBL, DMF and DMSO at a room temperature are respectively $0.3 \mathrm{mmHg}$, $0.375 \mathrm{mmHg}, 1.5 \mathrm{mmHg}$ and $2.7 \mathrm{mmHg}$. Higher saturated vapor pressure of the solvent can lead to a lower boiling point of solvent and a faster volatile. High boiling point can lead the time and temperature of crystallization to rise. As the boiling point $\left(153^{\circ} \mathrm{C}\right)$ of DMF is lower, the crystal nucleus is gradually reaching the largest size.

Although the saturation vapor pressure of GBL is higher than the DMSO, the crystal nucleus is smaller. This is because the size of the crystal nucleus is not only related to the saturation vapor pressure, but also influenced the solubility of $\mathrm{PbI}_{2}$. The solubility of $\mathrm{PbI}_{2}$ differs in each solvent. As shown in figure 3, when the temperature is under $75^{\circ} \mathrm{C}, 500 \mathrm{mg} \mathrm{PbI} 2$ is respectively dissolved into $1 \mathrm{ml}$ DMF, DMSO, GBL and NMP. As shown in figure 4, during a long-term observation under the room temperature, we have drawn a conclusion that the solubility of PbI2 in DMSO and DMF is better than GBL and much greater than NMP.

The film thickness has a great influence on the efficiency of solar cells. In this paper, as shown in figure 4 , we use the scanning electron microscope (SEM) to observe the cross section of $\mathrm{CH}_{3} \mathrm{NH}_{3} \mathrm{PbI}_{3}$ film. When we use the NMP solvent, the thickness of $\mathrm{CH}_{3} \mathrm{NH}_{3} \mathrm{PbI}_{3}$ film is about $432.5 \mathrm{~nm}$. When the GBL is about $530.2 \mathrm{~nm}$, the DMSO is about $621.3 \mathrm{~nm}$, and the DMF is about $1169 \mathrm{~nm}$. This result shows that the greater the solubility and saturated vapor pressure of 
ICETA 2015

solvent are, the greater the film thickness at the same speed of spin-coating is. 
MATEC Web of Conferences

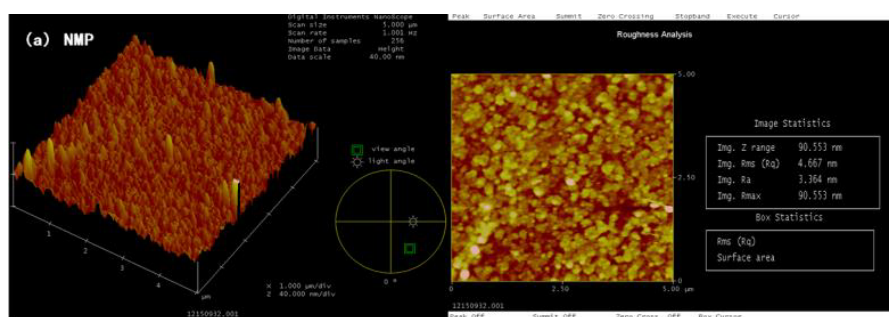

a )NMP

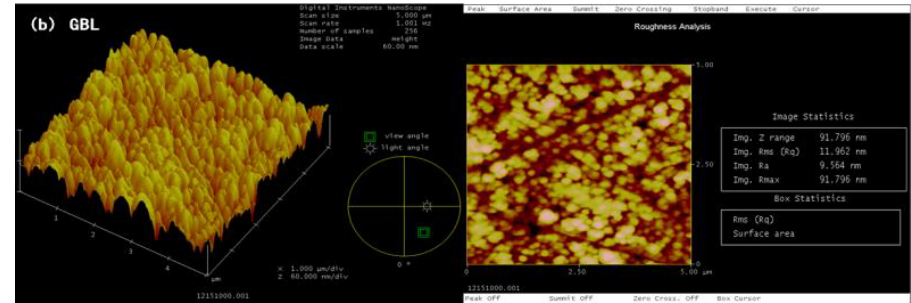

b) GBL

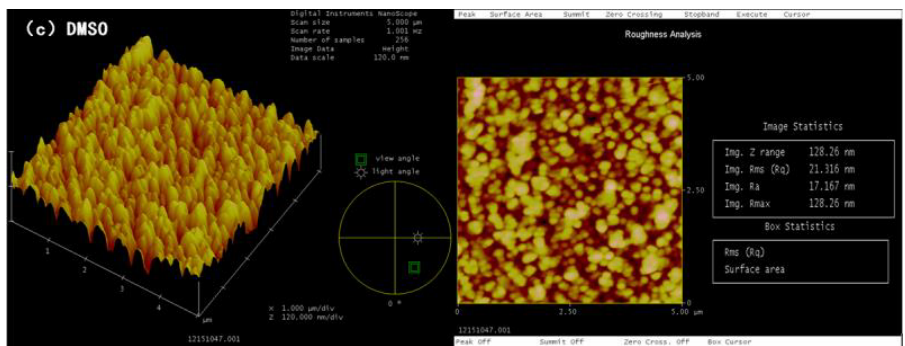

c) DMSO

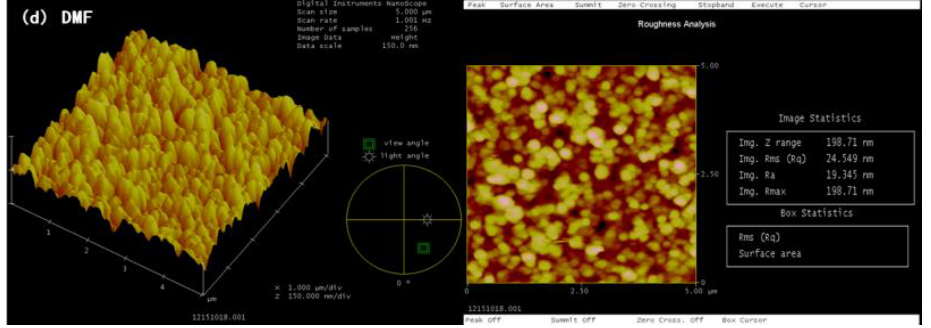

d) DMSO

Figure 2. AFM images of different solvents in $\mathrm{CH}_{3} \mathrm{NH}_{3} \mathrm{PbI}_{3}$ film

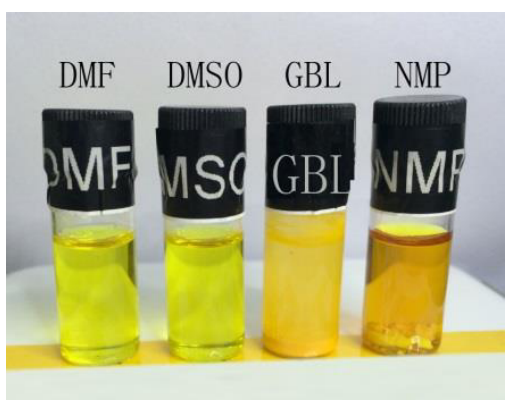

Figure 3. Dissolved situation of $\mathrm{PbI}_{2}$ at $75^{\circ} \mathrm{C}$ in DMF, DMSO, GBL and NMP. (DMF and DMSO: completely dissolves; GBL: colloidal suspension; NMP: partly dissolve) 


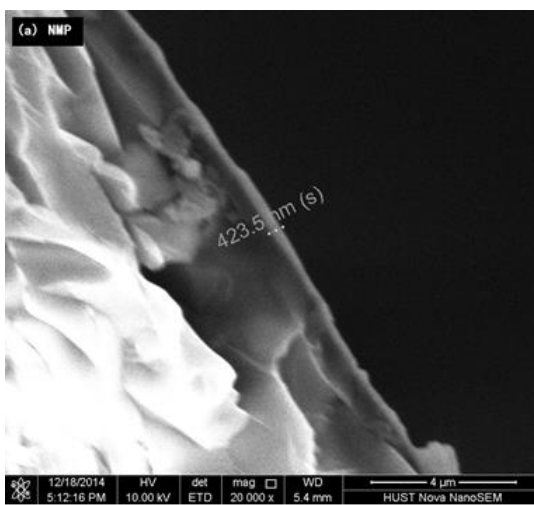

a) NMP

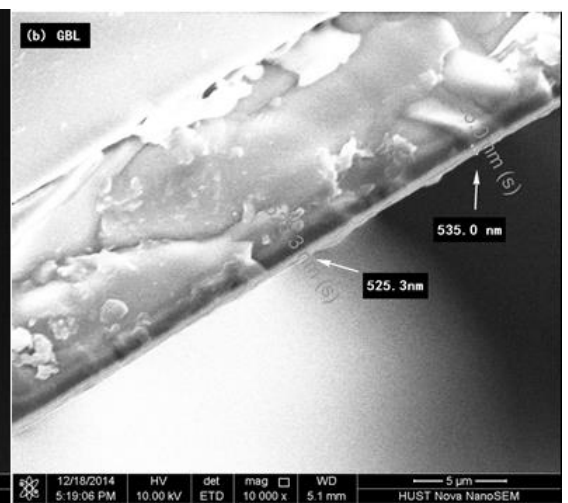

b) GBL

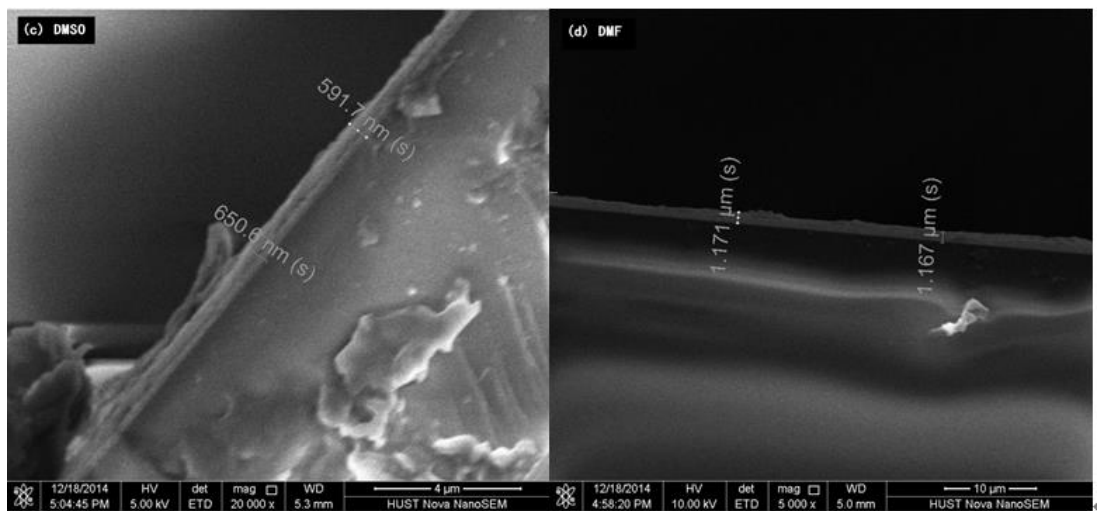

c) DMSO

d) DMF

Figure 4. SEM image of $\mathrm{CH}_{3} \mathrm{NH}_{3} \mathrm{PbI}_{3}$ films

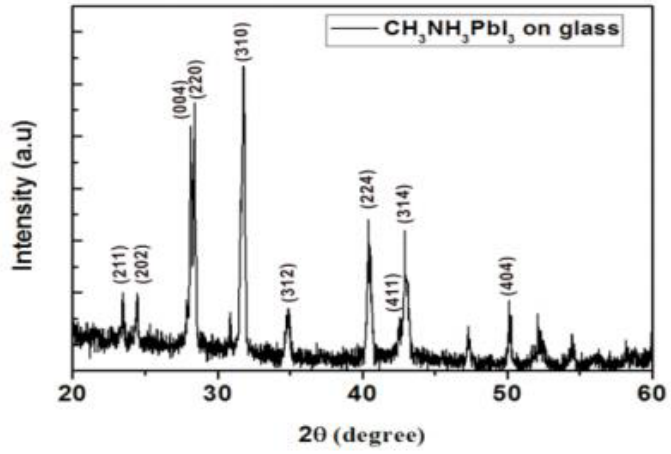

Figure 5. XRD pattern of $\mathrm{CH}_{3} \mathrm{NH}_{3} \mathrm{PbI}_{3}$

We study the $\mathrm{CH}_{3} \mathrm{NH}_{3} \mathrm{PbI}_{3}$ film by XRD to investigate whether the different solvent and morphology would influence the major constituents of $\mathrm{CH}_{3} \mathrm{NH}_{3} \mathrm{PbI}_{3}$. According to the diffraction pattern shown in figure 5 , the position and intensity of diffraction peak are consistent with the $\mathrm{CH}_{3} \mathrm{NH}_{3} \mathrm{PbI}_{3}$

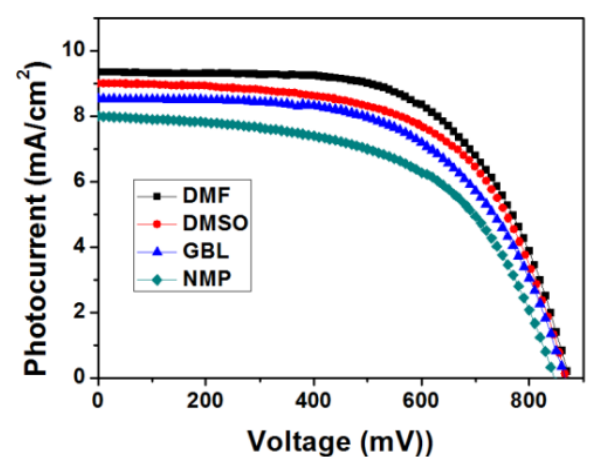

Figure 6. Device performance based on different solvents

structure which is shown in the literature ${ }^{[23]}$ (Because the four cases about XRD results are consistent, therefore, in this research, we only give XRD when using DMF as solvent). This result suggests that the different solvent does not change the crystal structure of $\mathrm{CH}_{3} \mathrm{NH}_{3} \mathrm{PbI}_{3}$. 


\subsection{Structural and optical properties}

As shown in Figure 6, it presents the current density-voltage (J-V) curves of the devices with four kinds of solvents. From the figure 6 , we can find that the device made of $\mathrm{CH}_{3} \mathrm{NH}_{3} \mathrm{PbI}_{3}$ perovskite film spin-cast from DMF solution exhibits the optimal performance among those four kinds of solvents. We can also find the specific data in table 1, the device with DMF solution exhibits open-circuit voltage $(V o c)=872 \mathrm{mV}$, short-circuit current $\left(J_{S c}\right)=9.35 \mathrm{~mA} / \mathrm{cm}^{2}$, and fill factor $(F F)=0.62$, corresponding to a photo-current conversion efficiency (PCE) of 5.05\% under AM1.5. In fact, DMF solvent has the highest saturation vapor pressure and the biggest solubility of $\mathrm{PbI}_{2}$ when the temperature is under $75^{\circ} \mathrm{C}$, so we can obtain the most thickness of $\mathrm{CH}_{3} \mathrm{NH}_{3} \mathrm{PbI}_{3}$ perovskite film, the thickest crystal nucleus and the best performance of solar cells device after the $\mathrm{PbI}_{2}$ reacts with $\mathrm{CH}_{3} \mathrm{NH}_{3} \mathrm{I}$ to form

Table 1. Performance of device based on different solvents

\begin{tabular}{lllll}
\hline Solvent & $\boldsymbol{V}_{\boldsymbol{~ o c}}(\mathbf{m V})$ & $\boldsymbol{J}_{\text {sc }}\left(\mathbf{m A} / \mathbf{c m}^{\mathbf{2}}\right)$ & $\mathbf{F F}$ & PCE (\%) \\
\hline NMP & $847 \pm 110$ & $7.96 \pm 0.91$ & $0.56 \pm 0.01$ & $3.78 \pm 0.12$ \\
GBL & $866 \pm 72$ & $8.52 \pm 0.54$ & $0.58 \pm 0.10$ & $4.28 \pm 0.08$ \\
DMSO & $865 \pm 85$ & $9.01 \pm 0.72$ & $0.60 \pm 0.06$ & $4.67 \pm 0.10$ \\
DMF & $872 \pm 43$ & $9.35 \pm 0.63$ & $0.62 \pm 0.08$ & $5.05 \pm 0.14$ \\
\hline
\end{tabular}

$\mathrm{CH}_{3} \mathrm{NH}_{3} \mathrm{PbI}_{3}$

Average and standard deviation values were obtained based on 18 cells from 6 different batches.

It is worth mentioning that the process of $\mathrm{CH}_{3} \mathrm{NH}_{3} \mathrm{PbI}_{3}$ precipitation formation in $\mathrm{PHJ}$ structure is more uncontrollable than mesostructured PSCs. It will easily lead to some flaws of surface morphology $[20,24]$. And the spin-coating method is prone to generate pinholes and surface defect. It will make the hole transport layer (HTL) directly contacts with the electronic transport layer (ETL), and then produces shunt, increases internal resistance. This is the reason why the photo-voltaic performance of PHJ-PSCs is unsatisfactory in this research, so we will through continuous improvements to improve it in the near future.

\section{SUMMARY}

The choice of solvents is the most basic step of the fabrication of monolithic PHJ-PSCs. In this paper, we prepare $\mathrm{CH}_{3} \mathrm{NH}_{3} \mathrm{PbI}_{3}$ perovskite film by two-step method, and analyze the influence of different solvents to the surface morphology and film thickness of the $\mathrm{CH}_{3} \mathrm{NH}_{3} \mathrm{PbI}_{3}$ film on the PHJ-PSCs. The results show that the saturation vapor pressure and solubility of the solvent can affect the thickness of $\mathrm{CH}_{3} \mathrm{NH}_{3} \mathrm{PbI}_{3}$ perovskite film and the size of the crystal nucleus, thus, they will further affect the photo-voltaic performance of device. As the DMF has appropriate saturation vapor pressure and the best solubility of $\mathrm{PbI}_{2}$ at the room temperature, thus, by using DMF as solvent of $\mathrm{PbI}_{2}$, we can obtain the better photo-voltaic performance than that of NMP, DMSO and GBL.

\section{REFERENCES}

[1] Sarciftci N S, Smilowitz L. \& Heeger A J. et al. 1992 Photoinduced electron transfer from a conducting polymer to buckminsterfullerene. Science, 258(5087): 1474-1476.

[2] Yu G, Gao J, Hemmelen J C, Wudl F. \& Heeger A J. 1995. Polymer photovoltaic cells enhanced efficiencies via a network of internal donor-acceptor heterojucntions. Science, 270(5243): 1789-1791.

[3] Kim M et al. 2014. Electrical performance of organic solar cells with additive-assisted vertical phase separation in the photoactive layer. Adv. Energy Mater, 4(2): 1300612.

[4] O'regan, B \& Grfitzel M. 1991. A low-cost, high-efficiency solar cell based on dyesensitized. Nature, 353: 737-740.

[5] Yella A et al. 2011. Porphyrin-sensitized solar cells with cobalt (II/III)-based redox electrolyte exceed 12 percent efficiency. Science, 334(6060): 629-634.

[6] Kim H S et al. 2012. Lead iodide perovskite sensitized all-solid-state submicron thin film mesoscopic solar cell with efficiency exceeding 9\%. Sci. Rep, 2: 591.

[7] Park N G.2013. Organometal perovskite light absorbers toward a $20 \%$ efficiency lowcost solid-state mesoscopic solar cell. J. Phys. Chem. Lett., 4: 2423-2429.

[8] Gevorgyan S A, Alstrup J. \& Kress F C. 2009. A roll-to-roll process to flexible polymer solar cells: model studies, manufacture and operational stability studies. $J$. Mater. Chem., 19: 5442-5451.

[9] Na SI, Kim S S, Jo J \& Kim D Y. 2008. Efficient and flexible ITO-free organic solar cells using highly conductive polymer anodes. Adv. Mater, 20: 4061-4067.

[10]Hou $\mathrm{S}$ et al. 2012. Flexible conductive threads for wearable dye-sensitized solar cells. J. Mater. Chem., 22: 6549-6552.

[11] Snaith H J. 2013. Perovskites: the emergence of a new era for low-cost, high-efficiency solar cells. J. Phys. Chem. Lett., 4: 3623-3630.

[12]Ball J M, Lee M M, Hey A \& SnaithH J. 2013. Low-temperature processed mesosuperstructured to thin-film perovskite solar cells. Energy Environ. Sci, 6, 1739-1743.

[13] Huanping Zhou et al. 2014. Interface engineering of highly efficient perovskite solar cells, Science, 10(1126): 345-542.

[14]Chen Q. et al. 2014. Planar heterojunction perovskite solar cells via vapor assisted solution process. J. Am. Chem. Soc., 136(2): 622-625.

[15] Heo J H. et al. 2013. Efficient inorganic-organic hybrid heterojunction solar cells containing perovskite compound and polymeric hole conductors. Nat. Photon, 7(6): 486-491.

[16]Wojciechoski K, Saliba M, Leijtens T, Abate A. \& Snatih H. 2014. Sub $150 \mathrm{uC}$ processed me- 
so-superstructured perovskite solar cells with enhanced efficiency. Energy Environ. Sci, 7: 1142-1147.

[17]Xingb G. et al. 2013.Long-range balanced electron and hole transport lengths in organic-inorganic $\mathrm{CH}_{3} \mathrm{NH}_{3} \mathrm{PbI}_{3}$. Science, 342(6156): 344-347.

[18] Stranks S D. et al. 2013. Electron-hole diffusion lengths exceeding 1 micrometer in an organometal trihalide perovskite absorber. Science, 342(6156): 341-344.

[19] Mingzhen Liu1, Michael B. Johnston1 \& Henry J. Snaith1. 2013. Efficient planar heterojunction perovskite solar cells by vapour deposition, Opticletter, 19(501): 395-403.

[20]Zhang Weihao Peng Xiaochen \& Feng Xiaodong. 2014. Recent progress of perovskite solar cells. Electronic Components and Materials. 33(8):7-11.

[21] Burschka J, Pellet N. \& Moon S J, et al. 2013. Sequential deposition as a route to high-performance perovskite-sensitized solar cells. Nature, 499(7458): 316-319.

[22] Ku Zhiliang. 2014. The Optimization and Design of Counter Electrodes for Mesoscopic Solar Cells Candidate. Wuhan: Huazhong University of Science and Technology.

[23] Im J, Lee C. \& Lee J, et al. 2011. 6.5\% efficient perovskite quantum-dot-sensitized solar cell. Nanoscale, 3(10): 4088-4093.

[24]Epron G E, Burlakov V M, Docampo P, Goriely A. \& Snaith H J. 2014. Morphological control for high performance, solution-processed planar heterojunction perovskite solar cells. Adv. Funct. Mater 24(1): 151-157. 